\title{
Volume 2 Issue 2
}

\section{Californian Journal of Health Promotion 2004 Table of Contents}

\author{
Cover (Front and Back) \\ CJHP Editorial Board \\ Table of Contents \\ The Editor's Corner
}

\section{Content}

\section{$\underline{\text { Pages }}$

\section{PROFESSIONAL UPDATES}

SOPHE Corner

\section{COMMENTARY}

A Commentary on "A Health Education Perspective on Sexual Risk Taking

Ansa Ojanlatva

\section{HEALTH EDUCATION PRACTICE}

Applying the Seven Principles for Good Practice in Undergraduate Education: Improving Research Writing Skills in a Writing-Emphasis Health Counseling Course

Kathleen Schmalz, Steve Feyl, Edward A. Schmalz

\section{THEORY AND RESEARCH}

A Survey of Dietary and Exercise Habits and Perceived Barriers to Following a Healthy Lifestyle in a College Population Kathryn Silliman, Kathleen Rodas-Fortier, Michelle Neyman

Births to Teens Older and Younger Than 17 Years in San Bernardino County and

California: Variables Associated with Infant Mortality and Survival

Kofi Adade Boafo, Bruce Smith, Naomi N. Modeste, Thomas J. Prendergast, Jr.

Southern California Elementary Physical Education Specialists and Non- Specialists:

Beliefs and Behaviors of the Ideal Purpose and Actual Function of Elementary Physical Education

Anne Farrell, Sharon Thompson, Gloria Naper Owen 